\title{
Stressful Work, Citizenship Behaviour and Intention to \\ Leave the Organization in a High Turnover \\ Environment: Examining the Mediating Role of Job Satisfaction
}

\author{
Pascal Paillé \\ Dept. of Management, Université Laval \\ Québec (QC) G1K 7P4, Canada \\ Tel: 1-418-656-2131 E-mail: pascal.paille@fsa.ulaval.ca
}

\begin{abstract}
This study investigates the extent to which job satisfaction mediates the relationship between job stress work outcomes, such as intention to leave the employer and citizenship behaviour (OCB). Job satisfaction is examined as a mediator between stress and intention to leave, and OCB. The procedure advocated by Baron and Kenny (1986) was selected for the mediation test. The result pattern across both samples was very similar. While no relationship was found between stressful work and OCB, stressful work increased the desire to leave the employer. Job satisfaction had a positive negative effect on OCB and a strong negative effect on intention to leave. Job satisfaction fully mediated the relationship between stressful work and intention to leave the employer. Our data suggest that an employee who experiences job satisfaction can support stressful work induced by his or her professional environment.
\end{abstract}

Keywords: Perceived stressful work, Citizenship behaviour, Intention to leave, High turnover environment, Job satisfaction 


\section{Introduction}

Increased job stress seems to be related to economic competitiveness (Sauter, Murphy and Hurrell, 1990). Brun and Lamarche (2006) affirm that the cost of job-related stress is evaluated at 20 billion Euros for the European community and 300 billion dollars for the United States. Johnson and Indvik (1996) note that in North America, stress is responsible each year for the loss of some 100 million working days. Perhaps this is why the topic of stressful work has generated abundant literature. Recently, Kelloway, Teed and Kelley (2009) reported that "between 2000 and 2005, the number of articles using the keyword stress has increased by almost 50 per cent (from 4,021 to 5,928)." Later in their article, Kelloway et al. indicate that over 67,000 studies were published on stressful work. Nevertheless, despite extensive research, Ganster and Schaubroeck (1991) affirm that most research on job stress has focused on determinants rather than outcomes (e.g., organizational citizenship behaviour, intention to leave, productivity, etc.).

Although determinants of stressful work are well known, earlier research studies show that stressful work decreases wellbeing in the workplace (Danna and Griffin, 1999; Tetrick and LaRocco, 1987), increases psychological distress at work (Van der Doef and Maes, 1999; Sluiter, Van deer Beek, and Frings-Dresen, 1999), fosters violence among colleagues (Mueller, De Coster, and Estes, 2001) and causes burnout (Aspinwall and Taylor, 1997). Moreover stressful work fosters decisions to leave the employer (e.g., Firth, Mellor, Moore, and Loquet, 2004; de Croon, Sluiter, Blonk, Broersen, and Frings-Dresen, 2004), increases absenteeism (Brun and Lamarche, 2006) and affects employee productivity (Jex, 1998; Motowidlo, Packard, and Manning, 1986).

Previous empirical research (e.g., Kemery, Bedeian, Mossholder, and Touliatos, 1985; LeRouge, Nelson, and Blanton, 2006; Parasuraman, and Alutto, 1984; Tuten and Neidermeyer, 2004) indicates that stressful work environments increase job dissatisfaction. Although existing empirical research provides many findings showing that job stress is associated with undesirable organizational outcomes, the basic logic behind these findings is that job stress increases job dissatisfaction, thereby motivating decisions to quit and absenteeism. However, rare are the studies that examine job satisfaction rather than job dissatisfaction under work environment pressure (Podsakoff, LePine, and LePine, 2007). Concomitantly, few empirical studies examine the relationship between job stress and organizational citizenship behaviour (OCB). Because OCB has become a major research topic in the last decade, the lack of research associating job stress and OCB is surprising. Recently, Bolino and Turnley (2005, p. 740) pointed out that today "the ideal worker is an employee who not only demonstrates high levels of task performance, but also engages in high levels of contextual performance or OCB as well." OCB refers to several elements of work activity not fully denoted by the traditional concept of job performance (Harrison, Newman, and Roth, 2006) that enhance organizational effectiveness (Organ, MacKenzie, and Podsakoff, 2006). Moreover, OCB can be viewed as the first step of a withdrawal process, suggesting increases in lateness and absenteeism when an employee dissociates from OCB (Harrison et al., 2006). 
This paper shows how job satisfaction helps an employee endure stressful work. More precisely, we investigate the extent to which job satisfaction mediates the relationship between stressful work and the outcomes of intention to leave the employer and OCB. Although recent studies provide data showing such a mediating role (Fried, Shirom, Gilboa, and Cooper, 2008; Villanueva and Djurkovic, 2009), more research is needed. In particular, current research has neglected to consider OCB. Because there is some evidence showing that OCB contributes to organizational effectiveness (Bolino, Turnley, and Bloodgood, 2002) and that decisions to quit decrease organizational effectiveness (Griffeth, Hom, and Gaertner, 2000) it is important to examine how exactly job satisfaction is related simultaneously to OCB and the decision to quit under stressful work conditions. Thus, the general purpose of the research reported in this study is to gain a better understanding of the concept by examining the mediating role of job satisfaction on the relationship between job stress, intention to leave the organization and OCB.

\section{Literature review and Hypotheses}

\subsection{Job Stress and Intention to Leave the Employer}

The relationship between job stress and intention to leave the employer has been examined by many researchers. Current data in the literature indicates that the perception of a stressful work environment favours employee decisions to truly leave their organization (Johnson and Indvik, 1996). Gupta and Beehr (1979) have shown that job-related stress better explains an intention to leave rather than the resignation itself. Based on their empirical results, Gupta \& Beehr explain that employees exposed repeatedly to stress situations may experience a desire to quit without necessarily resigning in fact, because many external factors may impede the decision (for example, job market conditions, spouse's job, social fabric, etc.). Gupta and Beehr (1979) were among the first to observe the impact of job stress on intention to leave. Their results show that the experience of stress significantly increases employee intentions to leave their organization. Although some data show no relationship (e.g., Hendrix, Ovalle, and Troxler, 1985, Tuten and Neidermeyer, 2004), most research overall provides significant relationships suggesting that the more employees perceive their job as stressful, the more their intention to leave their organization increases (e.g., Firth, Mellor, Moore, and Loquet, 2004; Gupta and Beehr, 1979; Kemery, Bedeian, Mossholder, and Touliatos, 1985). Thus,

Hypothesis 1: Job stress and intention to leave will be positively related

\subsection{Job Stress and $O C B$}

OCB has received a great deal of attention. Organ (1988, p. 4) defines OCB as "discretionary individual conduct, not directly or explicitly recognized by the formal system of compensation contributing to the general proper functioning of the organization that does not arise from the prescribed role or tasks of the job, in other words, the specific terms of a contract between employees and organizations; this behaviour arises rather from personal choices, such that its omission is not generally understood as punishable." Because it increases organizational efficiency by increasing production, improving the quality of service provided, raising client satisfaction or decreasing customer complaints (Podsakoff, 
MacKenzie, Paine, and Bachrach, 2000), OCB is valued by employers (Organ et al., 2006). OCB develops through the voluntary efforts of employees to exceed prescribed instructions and tasks. These efforts are oriented towards two major targets, with members of the organization being the first target. In this case, OCB is revealed as helping (forms of behaviour reflecting social, moral or practical assistance). Helping may reflect significant traits such as altruism, conciliation and even courtesy. Giving and receiving help strengthens ties between employees. Helping promotes the desire to reciprocate, contributes to learning the ropes and frees management control over tasks, allowing management to concentrate on developing goals, etc.

A few studies have examined the relationship between job stress and OCB and provided different findings. Using a sample of nurses, Motowidlo, Packard, and Manning (1986) provide data showing that interpersonal effectiveness is not influenced by both the frequency and intensity of stressful events, but rather by subjective stress. Despite these findings and because interpersonal effectiveness aggregates different dimensions such as concentration, perseverance, composure, morale, teamwork cooperation, sensitivity to patients, adaptability and caring for uncooperative patients, it is difficult to distinguish how exactly OCB and stress are related. More recently, Bolino and Turnley (2005) studied the effects of individual initiatives on job-related stress. Based on empirical data, Bolino and Turnley (2005) show that a high level of individual initiative and ensuing efforts can lead to stress in the workplace, thereby suggesting a health cost associated with employees. Thus, while Motowidlo et al. (1986) report a negative relationship, Bolino and Turnley (2005) report a positive relationship between stressful work and OCB.

Several additional empirical research studies could be raised. This research provides data addressing stressful events (e.g., role conflict, ambiguity and overload) rather than job stress. Thus, in their literature review on OCB, Podsakoff, MacKenzie, Paine, and Bachrach (2000) report negative relationships between role ambiguity and altruism, and between role conflict and altruism. An overview of the literature on stress suggests that authors (e.g., Bartol, 1979; Cropanzano, Howes, Grandey, and Toth, 1997; Jex and Gudanowski, 1992) frequently use measures of ambiguity and role conflict in the measurement of stress. Finally, the results of Podsakoff et al. (2000) suggest that improper instructions (conflict) or unclear instructions (ambiguity) disrupt employees carrying out their work. In addition, conflict and ambiguity hamper the willingness of employees to support their colleagues when they encounter difficulties. Although these studies do not measure stress directly, they provide a proxy relationship with risk factors of work stress. Consequently,

Hypothesis 2: Job stress and OCB will be negatively related

\subsection{Mediating Role of Job satisfaction}

Examining the mediating role of job satisfaction between job stress and outcomes is consistent with the consensus definition of Granny, Smith and Stone (1992) whereby job satisfaction is "an affective (that is, emotional) reaction to one's job, resulting from the incumbent's comparison of actual outcomes with those that are desired (expected, deserved, and so on.)" Recent findings by Podsakoff et al. (2007) suggest that it is important to 
distinguish hindrance-stressors and challenge-stressors to better understand the relationship between work stressors and retention criteria. Using a meta-analysis technique, Podsakoff and his colleague (2007) have reported that while hindrance-stressors decrease job satisfaction and increase turnover intentions, challenge-stressors increase job satisfaction and decrease turnover intentions.

Previous research suggests that job satisfaction may play a mediating role between job stress and intention to leave the employer, and OCB. First, Van der Doef and Maes (1999) identified sixty-three studies on stressful work conducted between 1982 and 1997. Previous empirical research shows that the perception of a stressful work environment has a negative impact on job satisfaction (e.g., Kemery, Bedeian, Mossholder, and Touliatos, 1985; LeRouge, Nelson, and Blanton, 2006; Parasuraman and Alutto, 1984; Tuten and Neidermeyer, 2004). Secondly, extensive data show that job satisfaction decreases intention to leave the organization (e.g., Blau, 2007; Lauver and Kristof-Brown, 2001; Poon, 2004; Tett, and Meyer, 1993) and increases OCB (e.g., Bateman \& Organ, 1983; Blakely, Andrews, and Fuller, 2003; Podsakoff, MacKenzie, Paine, and Bachrach, 2000). Some recent research has provided interesting results that can help us formalize the mediating role of job satisfaction (Fried, Shirom, Gilboa, and Cooper, 2008; Villanueva, and Djurkovic, 2009). Villanueva and Djurkovic (2009) find that job satisfaction partially mediates the relationship between occupational stress and intention to leave the organization. Using structural equation modeling, Fried et al. (2008) provide an interesting step. They found that role stress was directly related to job performance through job satisfaction and was indirectly related to job performance through propensity to leave. Although both studies provide encouraging results, they do not consider OCB. However, given that job stress is positively related to job satisfaction, job satisfaction is negatively related to intention to leave the organization and job satisfaction is positively related to OCB, we can expect a mediating role of job satisfaction. Thus,

Hypothesis 3: Job satisfaction mediates the relationship between stressful work and work outcomes (intention to leave the employer and helping).

\section{Method}

\subsection{Participants}

Because the profession of engineer (Igbaria and Siegel, 1992) is acknowledged as stressful occupation, the sample of the present study involved engineers. Alumni who graduated from a French engineering school were contacted for this study. Out of the 1000 prospective participants, 138 provided usable questionnaires (13.8\%). Thus, the sample consisted of 138 individuals (109 men, 28 women, 1 undetermined). All respondents worked in the industry and held an operational position. The average age was 36.8 years (S.D. $=9.5$ years). The experience overall average was 12.5 years $(S . D . \quad=9.1$ years $)$.

\subsection{Measure}

Perceived stressful work was measured with the three-item scale (e.g., Job concerns follow me home at night) developed by Mueller, De Coster, and Estes (2001). Job satisfaction was 
measured with the three-item scale (e.g., I am generally satisfied with the kind of work that I do for this organization) of Hackman and Oldham (1975). Intention to leave the organization was measured using the scale (e.g., I frequently consider leaving my organization) developed by Lichtenstein, Alexander, McCarthy, and Wells (2004). OCB was measured with a selection of four items of the scale developed by Podsakoff, MacKenzie, Moorman, and Fetter (1990), (e.g., I consider the impact of my actions on my coworkers). Finally, items were measured on a five-point Likert-type scale, ranging from 1 (disagree completely) to 5 (agree completely).

\section{Results}

Prior to the hypothesis testing, the full information saturated measurement model was analyzed. Chi-square statistics were used to analyze data. The more a value is small, the better the fit. Likewise, comparative-fit-index (CFI), the non-normed-fit index (NNFI) and root mean square error of approximation (RMSEA) were also used. Given the lack of consensus for both CFI and NNFI values (>.90 for Medsker, Williams, and Holahan, 1994 and $>.95$ for $\mathrm{Hu}$ and Bentler, 1999), we chose to consider acceptable values between .90 and .95. For the RMSEA, values in the .05 to .08 range provided an acceptable fit (Schermelleh-Engel, Moosbrugger, and Müller, 2003).

Table 1. reports the completely standardized item loadings for the model $(\mathrm{N}=138)$

\begin{tabular}{lll}
\hline Items & \multicolumn{2}{c}{ Loadings } \\
Stress 1 & .689 & $* * *$ \\
Stress 2 & .303 & (removed) \\
Stress 3 & .800 & $* * *$ \\
Satisfaction 1 & .859 & $* * *$ \\
Satisfaction 2 & .708 & $* * *$ \\
Satisfaction 3 & .541 & $* * *$ \\
Intention to leave 1 & .790 & $* * *$ \\
Intention to leave 2 & .650 & $* * *$ \\
Intention to leave 3 & .710 & $* * *$ \\
OCB-O 1 & .620 & $* * *$ \\
OCB-O 2 & .674 & $* * *$ \\
OCB-O 3 & .740 & $* * *$ \\
\hline
\end{tabular}

The measurement model provided a good fit, $\chi^{2}(50)=77.6, \mathrm{p}<.000, \mathrm{CFI}=.93, \mathrm{NNFI}=.91$, RMSEA $=.06$. Means, standard deviations and correlations among the variables are presented in Table 2. While stress was negatively related to job satisfaction $(r=-.297, p$ $<.01)$, it was not significantly related to OCB $(\mathrm{r}=.043$, ns). Job satisfaction was negatively related to intention to leave $(\mathrm{r}=-.605, \mathrm{p}<.01)$ and positively related to OCB $(\mathrm{r}=.195, \mathrm{p}$ $<.05)$. A few correlations were different. Perceived stress was not related to intention to leave $(r=.160, n s)$. Finally, intention to leave was not related to OCB $(r=-.160, n s)$. 
Table 2. Mean, standard deviation, and correlations among variables $(\mathrm{N}=138)$

\begin{tabular}{lcccccc}
\hline & Mean & SD & Stress & Satisfaction & Leave & OCB \\
& & & & & & \\
Stress & 3.10 & 1.11 & $(.72)$ & & & \\
Satisfaction & 3.43 & 0.81 & $-.297 * *$ & $(.73)$ & & \\
Leave & 2.50 & 0.85 & .160 & $-.605 * *$ & $(.72)$ & \\
OCB & 3.70 & 0.76 & .043 & $.195 *$ & -.160 & $(.79)$ \\
\hline$* p<.05 ; * p<.01$ & & & & & &
\end{tabular}

Given that the main purpose of this study was to examine the mediating effect of job satisfaction on the relationship between job stress and intention to leave the organization, and OCB, we used the procedure defined by Baron and Kenny (1986) for the mediation test. Table 3 provide results of the mediation test. Equation 1 indicates that perceived stress was negatively related to job satisfaction $(\beta=-.30, p<.05)$.

Table 3. Mediation test

Mediator

Job satisfaction

OCB
Outcomes

Intention to leave

$\begin{array}{lrr}\text { Equation } 1 & & \\ \text { Age } & -.25 & \\ \text { Tenure } & .38 & \\ \text { Stress } & -.30 & * * \\ & & \\ \quad & .08 & \\ \quad \text { Overall } \mathrm{R}^{2} & 4.28 & * *\end{array}$

Equation 2

Age

Tenure

Stress

Overall $\mathrm{R}^{2}$

Overall F

Equation 3

Age

Tenure

Stress

Satisfaction

Overall $\mathrm{R}^{2}$

Overall $\mathrm{F}$

$*$ p. $=.05 ; * * \mathrm{p}=.01 ; * * * \mathrm{p}=.000$
.42

$-.20$

$-.09$

.04

2.24

.47

$-.26$

$-.03$

$.19 *$

.08

3.01

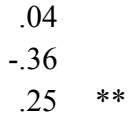

.12

$6.23 * *$

$-.11$

$-.19$

.07

$-.60 * * *$

.45

$27.49 * * *$ 
Equation 2 indicates while stress was not related to OCB $(\beta=-.09$, ns), it was positively related to intention to leave the employer $(\beta=.25, \mathrm{p}<.05)$. Finally, although stress was not related to $\mathrm{OCB}$, Equation 3 suggests that job satisfaction fully mediated the relationship between perceived stress and OCB, and shows that job satisfaction fully mediated the relationship between perceived stress and intention to leave the employer.

\section{Discussion}

This study represents an effort to examine the relationships between stressful work, job satisfaction, intention to leave and OCB. More precisely, the objective of this research was to examine whether job satisfaction plays a mediating role on the relationship between stressful work and intention to leave, and OCB. We chose to examine this mediating effect in a high turnover environment. While no relationship was found between perceived stressful work and OCB, perceived stressful work increased the desire to leave the employer. Job satisfaction had a positive negative effect on OCB and a strong negative effect on intention to leave. Job satisfaction fully mediated the relationship between perceived stressful work and intention to leave the employer. The results highlight the importance of employee job satisfaction in stressful environments.

\subsection{Theoretical Implications}

When taken as a whole, by providing additional results, our study complements previous research. Although the mediating role of job satisfaction on the relationship between stress work and outcomes is known with the recent findings of Fried et al. (2008) and Villanueva and Djurkovic (2009), our research is the first to show such mediation in high turnover environments.

Consistent with previous findings (e.g., LeRouge et al., 2006), job satisfaction was related to stressful work. Furthermore, consistent with previous empirical research (Firth et al., 2004; Gupta and Beehr, 1979; Kemery et al., 1985), stressful work was related to intention to leave the employer. Consistent with previous recent findings (Fried et al., 2008; Villanueva and Djurkovic, 2009), our results indicate that satisfactory employment mediates the relationship between stressful work and intention to leave the employer.

Contrary to previous data (Cropanzano et al., 1997), stressful work was unrelated to OCB. This result is surprising. Two explanations may be proposed to understand this result. First, it is possible that this result is related to the choice of measurement used to operationalize stressful work. We noted earlier that in the few empirical studies that have examined the link between stressful work and OCB, researchers (e.g., Bartol, 1979; Cropanzano et al., 1997; Jex and Gudanowski, 1992) have most often used the measurement of role ambiguity and role conflict to operationalize stressful work. Unlike these previous studies, we used the measurement of Mueller et al. (2001) that captures perceived stress at work. Secondly, it is possible that variables that were not used in this research explain why stressful work is not related to OCB. Following Halbesleben and Bowler (2005), the use of the social exchange framework provides an interesting means to understand why stressful work and OCB are not related. They argue that the most common method of reciprocating in exchange of positive 
work experiences is by performing OCB. OCB is viewed as what an employee offers in exchange of fair treatment or wellbeing in the workplace (Schaninger and Turnipssed, 2005). Possibly, the organizations involved in this research are aware of their stressful work conditions and have developed practices geared towards wellbeing, such as perceived organizational support. This is consistent with the premises of the social exchange theory and the results of Djurkovic and Villanueva (2009) that show that perceived organizational support mediates the relationship between stress and intention to leave.

Working as engineer is recognized to be stressful occupations (Igbaria and Siegel, 1992). In addition, knowledge industry is characterized by high turnover environment (Hemphill, 2005). Given this two particularities, the present study provides interesting findings. In the high turnover environments examined in this study, stress effects were buffered by job satisfaction. Thus, despite the existence of a stressful work environment, employers are able to retain their employees when the workplace generates great satisfaction.

\subsection{Practical Implications}

From a practical standpoint, the results of this study have interesting implications and suggest that special attention should be paid to job satisfaction. Lind and Otte (1994) note that in an organizational context, stress embodies a cost for both employers and employees. Each loses out. Stress results in loss of profit for employers and health problems for employees. The results of this study show the mediating role of satisfaction on the relation between perceived stress and behaviour in the workplace. Our results concur with the current trend in the literature on satisfaction which presents this attitude as a means of evaluating the work environment (e.g., Testa, 2001; Weiss, 2002). Our data suggests that an employee satisfied with his or her job can deal with stressful work conditions inherent in the professional environment. In light of the current inclination towards job intensification (Neboit and Vézina, 2002), modern organizations must define human resources policies centered on the development of employee satisfaction. Of course, the issue of satisfaction must not replace efforts to eliminate the risk of stress at the source. On the other hand, it should become a complementary objective to consider mitigating the harmful effects of stress at work and within the organization.

\subsection{Limitations and Future Research}

Despite the thought-provoking results of this study, several limitations exist that might constitute interesting avenues for future research. By choice, we have elected to discuss them in one same section. First, given the theme of this study, the emphasis was placed on two forms of behaviour in the workplace: intention to leave and helping. Our choice may be explained by the first part of this study. Obviously, there are many forms of on-the-job behaviour. It would be useful in future research to associate an intention to leave and helping behaviour with other forms of behaviour in the workplace (e.g., efficiency at work, professional deviance, etc.) to further explore the consequences of stressful work and the role of satisfaction. Secondly, the study of the role of satisfaction in the workplace is a central aspect of our research. However, sample size was small and we were unable to compare employees who are dissatisfied with those who are satisfied with their job. A third limit is 
linked to the choice of measuring job satisfaction as a global attitude. As indicated by Chen, Hui, and Sego (1998), there are two types of scales to measure satisfaction: those that measure satisfaction overall and those that measure facets of satisfaction. The scale developed by Hackman and Oldham (1975) used in this study refers to overall satisfaction and cannot be used to assess, for example, the impact of intrinsic and extrinsic components on the effects of stress related to on-the-job behaviour. Future research might improve knowledge of empirical relations by choosing a scale that would allow the measurement of different facets of satisfaction, rather than overall employee satisfaction. Fourth, the transversal measurement method used can induce shared variance bias. Shared variance bias is another limitation associated with this study. Although the measurement of concepts in this study concurs with the usual validity, a single data collection effort does not guarantee the stability of links obtained between the variables. Therefore, the results of this study must be qualified. Future research might collect data over several periods of measurement. To conclude, although engineers and nurses are different occupations, similar findings can be expected. Because the literature on nursing indicates that this occupation is characterized by cumulative shortages (Jean, 2005), a high turnover environment (Hayes et al., 2006) and stressful work (Seccombe and Smith, 1997), occupations such as nursing should be examined to detect possible invariants.

\section{References}

Aspinwall, L.G. \& Taylor, S.E. (1997). A stitch in time: Self-regulation and proactive coping. Psychological Bulletin, 121, 417-436.

Bateman, T. \& Organ, D., (1983). Job satisfaction and the good soldier: the relationship between affect and employee citizenship. Academy of Management Journal, 26, 586-595.

Baron, R.M., \& Kenny, D.A. (1986). The moderator-mediator variable distinction in social psychological research: Conceptual, strategic and statistical considerations. Journal of Personality and Social Psychology, 51, 1173-1182.

Bartol, K.M. (1979). Professionalism as Predictors of Organizational Commitment, Role Stress and Turnover: A Multidimensional Approach. Academy of Management Journal, 22, 815-821.

Blau, G. (2007). Does a corresponding set of variables for explaining voluntary organizational turnover transfer to explaining voluntary occupational turnover? Journal of Vocational Behavior, 70, 135-148.

Blakely, G., Andrews, M., \& Fuller, J. (2003). Are chameleons good citizens? A longitudinal study of relationship between self-monitoring and organizational citizenship behaviour. Journal of Business and Psychology, 18, 131-144.

Bliese, P.D. \& Britt, T.W. (2001). Social support, group consensus and stressor-strain relationships: social context matters. Journal of Organizational Behavior, 22, 245-436. 
Bolino, M.C. \& Turnley, W.H. (2005). The Personal Costs of Ctitzenship Behavior: The Relationship between Individual Initiative and Role overload, Job Stress, and Work-Family Conflict. Journal of Applied Psychology, 90, 740-748.

Bolino, M.C., Turnley, W.H., \& Bloodgood, J.M. (2002). Citizenship behavior and the creation of social capital in organizations. Academy of Management Review, 27, 505-522.

Brun, J.-P. \& Lamarche, C. (2006). Évaluation des coûts du stress au travail. Rapport de recherche, Chaire de Gestion de la Santé et de la Sécurité au Travail. Université Laval.

Chen, X.-P., Hui, C., \& Sego, D.J. (1998). The Role of Organizational Citizenship Behavior in Turnover: Conceptualization and Preliminary Tests of Key Hypotheses. Journal of Applied Psychology, 83, 922-931.

Cropanzano, R., Howes, J., Grandey, A. \& Toth, P. (1997). The relationships of Organizational Politics on support to work behaviours, attitudes, and stress. Journal of Organizational Behavior, 18, 159-180.

Danna, K. \& Griffin, R. (1999). Health and Well-Being in the Workplace: A Review and Synthesis of the Literature. Journal of Management, 25, 357-384.

De Croon, E.M., Sluiter, J.K., Blonk, R.W., Broersen, J.P.J. \& Frings-Dresen, M.H.W. (2004). Stressful Work, Psychological Job Strain, and Turnover: A 2-Year Prospective Cohort Study of Truck Drivers. Journal of Applied Psychology, 89, 442-454.

Firth, L. Mellor, D. Moore, K. \& Loquet, C. (2004). How can Managers reduce employee intent to quit? Journal of Managerial Psychology, 19, 170-187.

Fried, Yitzhak, Shirom, A., \& Gilboa, S., and Cooper, G. (2008). The Mediating Effects of Job Satisfaction and Propensity to Leave on Role Stress-Job Performance Relationships: Combining Meta-Analysis and Structural Equation Modeling. International Journal of Stress Management, 15, 305-328.

Ganster, D.C. \& Schaubroeck, J. (1991). Work Stress and Employee Health. Journal of Management, 17, 235-271.

Granny, C., Smith, P. and Stone, E. (1992). Job Satisfaction: advances in research and application, Lexington, MA: Lexington Books.

Griffeth, R., Hom, P. \& Gaertner, S. (2000). A Meta-Analysis of Antecedents and Correlates of Employee Turnover: Update, Moderator Tests, and Research Implications for the Next Millennuim. Journal of Management, 26, 463-488.

Gupta, N. \& Beehr, T.A. (1979). Job Stress and Employee Behaviors. Organizational Behavior and Human Performance, 23, 373-387.

Hackman, J.R. \& Oldham, G.R., (1975). Development of the job diagnostic survey. Journal of Applied Psychology, 60, 159-170. 
Halbesleben, J.R.B. \& Bowler, W.M. (2005). Emotional exhaustion and job performance: The mediating role of motivation. Journal of Applied Psychology, 92, 93-104.

Harrison, D., Newman, D.A. \& Roth, P. L. (2006). How important are job attitudes? Meta-Analytic comparisons of integrative behavioural outcomes and time sequences. Academy of Management Journal, 49, 305-325.

Hayes, L.J., O’Biren-Pallas, L., Duffield, C., Shamian, J., Buchan, J., Hughes, F., Spence Laschinger, H., North, N., \& Stone, P.W., (2006). Nurse turnover: A literature review. International Journal of Nursing Studies, 43, 237-63.

Hemphill, T. A. (2005). US offshore outsourcing of R\&D: accommodating firm and national competitiveness perspectives. Innovation: Management, Policy \& Practice, 7, 351-356.

Hendrix, W., Ovalle, N. \& Troxler, R. (1985). Behavioral and Physiological Consequences of Stress and Its Antecedent Factors. Journal of Applied Psychology, 70, 188-201.

Hu, L.T., \& Bentler, P.M. (1999). Cutoff criteria for fit indices in covariance structure analysis: conventional criteria versus new alternatives. Structural Equation Modeling, 6, $1-55$.

Igbaria, M. \& Siegel, S. R. (1992). An examination of the antecedents of turnover propensity of engineers: An integrated model. Journal of Engineering and Technology Management, 9, 101-126.

Jean, S. (2005). Projection de la main-d'oeuvre infirmière de 2004-2005 à 2019-2020, Ministère de la santé et des services sociaux, Gouvernement du Québec.

Jex, S.M. \& Gudanowski, D.M. (1992). Efficacity Beliefs and Work Stress: An Exploratory Study. Journal of Organizational Behavior, 13, 509-517.

Johnson, P.R. \& Indvik J. (1996). Stress and workplace violence: it takes two to tango. Journal of Managerial Psychology, 11, 18-27.

Judge, T., Bono, J. \& Locke, E., (2000). Personality and Job Satisfaction: The mediating Role of Job Characteristics. Journal of Applied Psychology, 85, 237-249.

Kelloway, E., Teed, M., \& Kelley, E. (2008). The psychosocial environment: towards an agenda for research. International Journal of Workplace Health Management, 1, 50-64

Kemery, E., Bedeian, A., Mossholder, K. \& Touliatos, J. (1985). Outcomes of role stress: a multisample constructive replication. Academy of Management Journal, 28, 63-75.

Lauver, K.J., \& Kristof-Brown, A. (2001). Distinguishing between Employees' Perceptions of Person-Job and Person-Organization Fit. Journal of Vocational Behavior, 59, 3454-3470.

Lease, S. (1998). Annual Review, 1993-1997: Work Attitudes and Outcomes. Journal of Vocational Behaviour, 53, 154-183.

LeRouge, C., Nelson A., \& Blanton, J. (2006). The Impact of Role stress fit and self-esteem on the job attitudes of IT professionals. Information \& Management, 43, 928-936. 
Lind, S. \& Otte, F. (1994). Management style, mediating variables, and stress among HRD professionals. Human Resource Development Quarterly, 5, 301-316.

Medsker, G.J., Williams, L.J., \& Holahan, P.J. (1994). A review of current practices for evaluating causal models in organizational behavior and human resources management research. Journal of Management, 20, 439-464.

Morrow, P.C., Suzuki, Y., Crum, M.R., \& Ruben, R. (2005). The role of leader-member exchange in high turnover work environments. Journal of Managerial Psychology, 20, 681-694.

Motowidlo, S.P., Packard, J.-S. \& Manning, M. (1986). Occupational stress: Its causes and consequences for job performance. Journal of Applied Psychology, 71, 618-629.

Mueller, C.W., De Coster, S. \& Estes S.B., (2001). Sexual Harassment in the workplace. Work and Occupations, 28, 411-446.

Neboit, M. \& Vézina, M. (2002). Évolution du travail, santé psychique et stress: points de repère, pp. 25-44. In : Neboit M., Vézina, M. (2002) Stress au travail et santé psychique, Éditions Octarès, Toulouse.

Newton, T.J. \& Keenan A. (1985). Coping with Work-Related Stress. Human Relations, 38, 107-126.

Organ, D., (1988). Organizational citizenship behavior: The good soldier syndrome, Lexington, MA : Lexington books.

Organ, D., Podsakoff, P. \& MacKenzie, S. (2006). Organizational Citizenship Behavior. Its Nature, Antecedents and Consequences. Sage Publications, Thousand Oaks.

Parasuraman, S. \& Alutto, J. (1984). Sources and Outcomes of Stress in Organizational Settings: Toward the Development of Structural Model. The Academy of Management Journal, 27, 330-350.

Podsakoff, N.P., LePine, J.A., \& LePine, M. A. (2007). Differential Challenge Stressor-Hindrance Stressor Relationships With Job Attitudes, Turnover Intentions, Turnover, and Withdrawal Behavior: A Meta-Analysis. Journal of Applied Psychology, 92, 438-454.

Podsakoff, P., MacKenzie, S., Moorma, R. \& Fetter, R., (1990). Transformational leader behaviors and their effects on followers' trust leader, satisfaction, and organizational citizenship behaviours. Leadership Quarterly, 1, 107-142.

Podsakoff, P., MacKenzie, S., Paine, J. \& Bachrach, D. (2000). Organizational Citizenship Behaviors: A Critical Review of the Theoretical and Empirical Literature and Suggestions for Future Research. Journal of Management, 26, 513-563.

Poon, J.M.L. (2004). Effects of performance appraisal politics on job satisfaction and turnover intention. Personnel Review, 33, 322-334. 
Sauter, S.L., Murphy, L.R. \& Hurrell, J.J., Jr. (1990). Prevention of work-related psychological disorders: a national strategy proposed by the National Institute for Occupational Safety and Health (NIOSH). American Psychologist, 45, 1146-1158.

Schaninger, W.S. \& Turnipssed, D.L. (2005). The Workplace Social Exchange Network: Its Effetc on Organizaitonal Citizenship Behavior, Contextual Performance, Job. In : Turnipseed, D.L. Handbook of Organizational Citizenship Behavior: A Review of 'Good Solder' Activity in Organizations. New-York, Novasciences Publisher.

Seccombe, I., \& Smith, G. (1997). Taking Part: Registered Nurses and the Labour Market in 1997. The Institute for Employment Studies, Brighton.

Sluiter, J.K., Van Der Beek, A.J. \& Frings-Dresen, M.H.W. (1999). The Influence of Work Characteristics on the Nedd for Recovery and Experienced Health: a Study on Coach Drivers. Ergonomics, 42, 573-583.

Sullivan, S. \& Bhagat, R. (1992). Organizational Stress, Job Satisfaction and Job Performance: Where Do We Go From Here? Journal of Management, 18, 353-374.

Testa, M. (2001). Organizational Commitment, Job Satisfaction, and Efforts in the Service Environment. The Journal of Psychology, 135, 226-236.

Tett, R.P., \& Meyer, J.-P. (1993). Job Satisfaction, Organizational Commitment, Turnover Intention, And Turnover: Path Analyses Based On Metaanalytic Findings. Personnel Psychology, 46, 259-293.

Tetrick, L.E. \& LaRocco, J.M. (1987). Understanding prediction, and control as moderators of the relationships between perceived stress, satisfaction, and well-being. Journal of Applied Psychology, 72, 538-543.

Tuten, T.L. \& Neidermeyer, P.E. (2004). Performance, satisfaction and turnover in call center. The effects of stress and optimism. Journal of Business Research, 57, 26-34.

Villanueva, D. \& Djurkovic, N. (2009). Occupational Stress and Intention to Leave Among Employees in Small and Medium Enterprises. International Journal of Stress Management, $16,124-137$.

Van der Doef, M. \& Maes, S. (1999). The Job Demand-Control (-Support) Model and psychological well-being: a review of 20 years of empirical research. Work and Stress, 13, 287-314.

Weiss, H. (2002). Deconstructing job satisfaction. Separating evaluations, beliefs and affective experiences. Human Resource Management Review, 12, 173-194. 